\title{
The Prestigious Status of Istanbul in Orhan Pamuk's Literary Form
}

\author{
Ahmed Hassan Ali Murshed \\ Research Scholar \\ Department of English \\ Faculty of Arts/ Aligarh Muslim University \\ Aligarh, UP, India \\ almurshed2018@gmail.com
}

Abstract

Love of the homeland is an innate instinct on which the human being was created. It is not strange that the individual loves his country in which he was born and raised and feels nostalgic for it when he/she leaves it to another state, so that is proof of the close relationship and the sincerity of belonging. Pamuk's passion for Istanbul is remarkable, and he is vitalist in portraying it in his literature. Mostly, all of Pamuk's novel plots are settled in Istanbul, but Pamuk's autobiographical novel Istanbul: Memories and The City gives much more about Pamuk's feelings towards his native city. It is devoted to both his memories from his childhood and Istanbul as a city and its meaning in his life as a writer. The book is composed of memories and emotions that have shaped his life forever.

As a skillful painter, Pamuk's concepts and perspectives of Istanbul are unique. He composes that there was no Ottoman painting that can undoubtedly oblige our visual tastes because we have been educated to view things in an alternate Western style. He is attracted to Antoine Melling, the eighteen-century painter, who "viewed the city as an Istanbuli, however, painted it as a reasonable looked at Westerner" (Pamuk, Istanbul: Memories and the City, 67). This paper will attempt to outline and discuss the significant status of Istanbul in Orhan Pamuk's writing, how he represents his close connection with it, and how he made Istanbul 
the story field of his novels. It also will focus on the importance of the geographical location of Istanbul as the center of the bridge of different cultures, religions, and ethnicities, which leads to conflict or coexistence.

Keywords: Istanbul, Bosporus, Melancholy, Memory, Nostalgia

Introduction

The Nobel Prized Turkish writer Orhan Pamuk was born on 7 July 1952, in Istanbul to a wealthy, Western, secular family. As a youngster, he went to Robert College High School and longed to turn into a painter. He started his engineering studies at the Technical University of Istanbul, yet at the age of 22 changed to journalism to fulfill his desire as an author. Cevdet Bey and His Sons, Pamuk's first novel shows up the Turkish family's narration, which extended to three generations. In Turkey, the novel was distributed in 1982. The first novel of him to be translated into English, The White Castle, occurred in the 1600s in Istanbul and investigates the dialogue between West, and East, a topic that repeats all through Pamuk's composing profession. In 2006, Pamuk was granted the Nobel Prize for Literature, and he is the foremost Turkish writer to get the award. Generally, the bestselling writer in his country is Pamuk, whose novels were translated into over sixty languages. (Anadolu-Okur, III).

Istanbul is not just the geographical place for the entire of Pamuk's novels. Nevertheless, it is a critical segment that physically and aesthetically works as a significant image for the various issues presented in his literary work. This inseparable connection between the city and Pamuk's writings also brings about misinterpretations, which transcendental rotate around the coarse difference between the West and the East. The metropolis's separated geographical location of the two continents, Asia and Europe, plainly exhibits the various twofold that involve a focal function in Pamuk's literary work. This partitioned structure of Istanbul has actuated the development of the metropolis as a spot. 
Two particular cultures are coming together, a location of experience that, while motivating discourse, likewise outlines the division between the two different sides. What makes Pamuk's position fascinating is the challenge he brings to this imagery, which has been related to the city of Istanbul. In his compositions, he utilized Istanbul not to portray its function as a bridge between the two societies yet instead to increase uncertainties about these two fold's fixed and pure qualities. The West and the East have been described.

Quickly, as a typical old capital, Istanbul shapes the lives of its citizens by its spirit, culture, and imperial past. On the other hand, it is a city that lives with specific sentimentsthe sense of defeat and loss, melancholy and pain, because of the lost power and glory (Shah, 37). Istanbul's city spaces inspire cultural and literary production while inducing a loss that informs the literary esthetic. The postmodern author, OrhanPamuk concentrates on materiality in the city and undercut by dream space to enable a transformation of the self in Istanbul's everyday life. Pamuk's particular brand of postmodern literary esthetic exhibits his literary form as explaining the possibilities of the novel to speak to the city palimpsest and the domain of architecture (Narayan, iv).

Istanbul is a shadow that follows Orhan Pamuk both throughout everyday life and writing. Its roads, buildings, and glorious past make a particular foundation of his books. It tends to be said that Istanbul is, in a manner the principal character of Pamuk's writing. Istanbul is where he was born, where he has found the world and discovered the importance of living in an old capital keeping privileged insights of the past, and confronting difficulties in the present. Istanbul was a wellspring of motivation of many recognized Turkish writers, for example, Tanpınar, Abdülhak Hisar, Yahya Kemal, and Ahmet Rasim. However, Orhan Pamuk is the author of the unique book, Istanbul: Memories and the City that reveals the unknown Istanbul, which synthesizes his memories from his early childhood and his impressions got from various sources-family conversations, public transportation, football 
matches, street inscriptions, books written both by Turkish and European writers. Since Pamuk has written his book about Istanbul as a painter, his book devoted to Istanbul is an original way of looking at this eternal city that shapes its citizens' lives (Weder, 49).

Ahmet Tanpınar, a great Turkish novelist and one of the most prominent Turkish authors of the 20th century, has written in his anthological essays about Istanbul published within the book of Five Cities. This old Ottoman capital was "the source of pride of the Empire and the whole Muslim world" for the generations after its conquest in 1453 . He has also emphasized that "the eyes of the whole East were directed on Istanbul, which was a brilliant mirror of the national life and which had completely national character in taste" (Almas, 73). The city has a double job; it fills in as a background to the drive. However, it additionally serves as a cupel, where all narrations are produced into one. The individual interests are the remains; however, the experience and the picture of the cityscape are still fascinating (H. E. Almas, 66).

The French author, Gustave Flaubert expressed his conviction in one of his letters that Istanbul would be the world's capital in a hundred years from then, but the truth was completely different. In a true sense of the word and old dilapidated, worn out, and melancholic capital of once the most powerful empire in the world, so Pamuk writes:

The city into which I was brought into the world was impoverished, shabby, and more separated than it had ever been in its long-term history. It has consistently been a metropolis of the remains and end-of-real depression. I have spent my survival on earth either doing combat with this despairing or (as all Istanbulies) making it my own. (Pamuk, Istanbul: Memories and the City, 6)

Pamuk has been building his relationship with his city using various materialspersonal visual impressions, family experiences, and memories, both Turkish and European writers' books, which helped him make his idea of Istanbul. The story can be read as 
memories of his childhood and youth and the life of his high esteemed and well-situated family, losing its reputation and wealth slowly, but still personifying the new elite of the modern Republic of Turkey. We can read it as a short narration of the metropolis, particularly on the Ottoman Empire's progress to the Turkish Republic looking for its new identity. The book titled Istanbul is perhaps the most important source for the research on the emotional map of the society living with feelings of defeat, loss of power, and significance that has been accepted or condemned to live with melancholy as a sentiment that follows its members as a destiny. The book argues that the city "does not have a center outside ourselves" is not only in the eyes. On the contrary, the city's idea also consists of reading books, newspapers, articles, street inscriptions, advertisements, and sounds.

Istanbul of Orhan Pamuk is a complex of the real and the imaginary, the visible and the fantasy. There was an impression that Pamuk's Istanbul is above all in his head, emotions, and visions in which there is no strong border between what exists and what is imagined. Spiritual affinity with the place of his birth and it is melancholy and finally, his decision to pursue his writing career. He uses both his self and the city of Istanbul as a text and explores different dimensions of being "in-between" the margins and the center, tradition, and modernity, East and West (Manzoor, 226). Pamuk's success in depicting Istanbul as the old capital lies in a poetic permeation of cultures in his spirit. He looks at the city with the eyes of its natives, visitors from the West, writers, poets, and painters. According to him, Istanbul's poetic texture consists of every kind of bizarreness, empyreal glory, and a bit of history. However, Pamuk is right when he says that the city's poetry opens itself only to him. Almost on every page of his book, he seeks a link with the past. He has answered the question of his favorite Turkish writer, Ahmet Tanpınar, who had written that the main question was "when and in what way will we connect to the past. 
Pamuk is capable of looking at the city both as to its citizen and a Westerner. Pamuk is incredibly successful in researching the city's spirit, its unique melancholy that is a crucial emotion produced by old, ruined, and neglected buildings, poverty and marginality, feelings of defeat, and loss of imperial glory. In most of Pamuk's writing, Istanbul is not only a solely city but also it turns to be an integral portion and interlaces with the story. He started composing Istanbul as a memoir by describing a specific period in his life, integrating his life events with his favorite city, Istanbul. Illustrating what has happened in his life at a particular point in time and parallel to how Istanbul has impacted his life and reflected how the city has affected and turns to be an essential part of his life (Priyadarshini, 152).

Undoubtedly, Pamuk has concentrated on his place's particular viewpoints, taking note of that, and his house is on the European side of the Bosporus. Nevertheless, from his balcony, he sees the narrow waterway in Asia. Likewise, he has described the landscape from the center of Bosporus Bridge, the scaffold between the two continents, noticing that it arranges the watcher neither in Europe nor Asia, yet interfaces him with both - a unique viewpoint that Istanbul brings to Turkish culture. Concerning Pamuk's feeling of Istanbul as a cultural area disturbing set up ideal models of West-East relationships, The White Castle remains as an important text; an unmistakable, efficient illustrating of the writer's position, it forms as a progression of personality experiments. The fascinating facets of Pamuk's depiction of Istanbul are the significance he provides to depression and an inclination that is viewed as a connection that joins all Istanbulies regardless of their cultural, social, or monetary status. It enables the author to address the complicated Turkish personality (Martins, 174).

What has to be underlined is the strong connection between Pamuk's specific imagining of Istanbul and his dealing with West-East inquiries, a connection to a great extent unremarked and lacking in basic discourse. Besides, The White Castle has not been inspected 
in detail as an Istanbul-focused content—nor as to the content that viably establishes Pamuk's Istanbul-focused composition of West-East confrontation. The city of Istanbul has become the dominant focal point of the Turkish writer and Noble Prize winner, Orhan Pamuk. His portrayal of Istanbul uncovers a landscape of contestation where two restricting structures of reference intercede and communicate in molding the city's personality and its occupants; precisely, a cosmopolitan Ottoman Islamic legacy and a nationalist Westernized current style. What makes the Bosporus different from other European streams, as per Pamuk, is its particular nature as a state of connectivity rather than a line of division.

Undoubtedly, Istanbul has an exceptional location, and its geographical situation changes it into a border metropolis because it is a scaffold that associates Europe with Asia. Additionally, it has been under the standard of various people groups and history and has an appreciated place of authority for many centuries. The different names it got an outline, among numerous different models that could be referenced here, why Istanbul can be viewed as a multicultural metropolis. Notwithstanding, its noticeable political and authentic significance that, on a basic level, might have made the city to be viewed as the focal point of the world had not kept Europeans from regarding Istanbul fringe in international and cultural terms (Martins, 171). My Name is Red pursues The Black Book in showing up a richly definite record of Istanbul, its geography, architecture, and regular daily life. Like, The White Castle, notwithstanding, My Name is Red presents Istanbul recouped from history, mainly from the late sixteenth century. The new novel's understanding -in this way- requires the acknowledgment of Pamuk's feeling that Istanbul is not recently a position of the combination and cultural crossbreeding. However, it has been such a spot for quite a long time as Sabah Salih (a Kurdish Professor) states that in Istanbul, East and West have been connected in sustained and prolonged encounters. 
Undeniably, that the writer (Orhan Pamuk) and the metropolis (Istanbul) are so firmly, anyone can not be perceived without the other, because Pamuk asserts that Istanbul is his city. He has extended his depression, delights, and anxieties since he was a youngster in this position. This unique connection with space causes Istanbul to reflect the novelist's emotions and those of the collectivity. By recognizing that Istanbul is his home, as the author roams through the city, reviewing his recollections, he changes Istanbul as the homeland into an image that typifies the country's personality (Martins, 173).

Basically, at the core of this memoir is his transcendental distinguishing proof and connection with his city; he says that "Istanbul's fate is my destiny: I am joining to this metropolis since it has made me who I am" (Pamuk, Istanbul: Memories and the City, 6). Pamuk catches the city's spirit, in other words, clearly, the truth that burdens the representative worth he provides for the city. Pamuk spent some time dedicate hüzün (sadness) in a whole chapter and shared sentiment of depression. He thinks that the metropolis of Istanbul endures it as its destiny as he mentioned it as "What I am attempting to illustrate is the hüzün of the whole city: of Istanbul" (Pamuk, Istanbul: Memories and the City, 80). The sentiment depicts the city's spirit and permits the novelist to talk about the destruction of the empire and the signposts that misfortune has fled the city scene and its occupants' sentiments, accordingly adding to clarify the last equivocal feeling of identity. There are differences between the hints of a great past and the republican drive to overlook or delete it. Consider Pamuk's critical tone:

In Istanbul, the remaining parts of a great past and development are wherever prominent. Regardless of how badly saved, they are regardless of how dismissed or trimmed in; they are by concrete monstrosities, the ornamented masjids, and different city landmarks. Just as the lesser rubbish of the empire in each side road and corner - the slight curves, 
wellsprings, and neighborhood mosques - cause grief on all who survive among them (Martins, 175).

An essential part of the city is its geography, how different parts relate to each other. Given the uninformed reader knows that Istanbul is clustered around the Bosporus. The flowing of water makes out the heart of the city spanned by bridges and crisscrossed by ferries and transverse by ships from all over the world, presenting a view of which all people in the city desire a slice of. Accordingly, Istanbul, and all the more explicitly the Bosporus waterway, as both a fringe space and a gathering point, is fundamental to our comprehension of cosmopolitanism. Thinking beyond the outskirts, Immanuel Kant (German Philosopher) received cosmopolitanism to conceptualize all-inclusive hospitality, transnational portability, and worldwide harmony (Aljahdali, 118). On the contrary, Pamuk ascribes the destruction of a cosmopolitan space in Istanbul to 'the Republic's establishment and the fierce ascent of Turkification'. The foundation of a new idea of Turkishness has stopped what was previously 'the fantastic, multicultural, polyglot Istanbul of the majestic era; the metropolis deteriorated, emptied itself, and turned into a monolingual city in white and black' (Weder, 145).

Obviously, in Istanbul, Pamuk broadens his self-portraying spot over the metropolis, so it is not just the space he has survived in for his entire life, but it is the place of creative mind and portrayal. In Istanbul, notwithstanding, metropolitan experience is significantly more critical as far as artistic creation, producing the figure of the author and his work. At nights, he wanders and walks around the forsaken place in the city that he arrives at a selfacknowledgment and settles on his survival time: to seek after a vocation as a novelist (Dollar, 28). During arguing with his mother about leaving the faculty of Engineering for potential life as a writer, he discovers comfort in dreaming about the roads. He will stroll shortly at night, "now I think that... in a few minutes, I would open the entryway and flee into 
the city's consoling roads; and having walked for five hours at night, would come back and take a seat at my table and catch their landscapes on paper" (H. E. Almas, 67).

Toward the end of his personal history, Pamuk remains on the edge of a metropolitan meaning of himself by composing his feeling for the metropolis. Istanbul, at that point, makes Pamuk what he is. Then again, Pamuk finds in Istanbul what he hopes to see. Blessed with humanities credits, Istanbul rises above its utilization as a background for Pamuk's character as it shows up in the text. However, it turns into the impression of the writer himself. However, the connection between oneself and the city talks not exclusively to personality, yet to numerous concerns. This metropolis of contrasts and chaos is to be invented, "maybe, we cannot resist adorning our metropolis like a family, because we do not have other choices. Yet, we need to choose which part of the metropolis we love and create reasons" (E. Almas, 69).

The metropolis of Istanbul is the narration background, yet the city is the capital of a great Empire. The city is set apart by the feeling of "sadness" (a sort of mixing of depression, nostalgia, and misery), and Pamuk exhibits that it is the equivalent sort of "sadness" that collects literary work by different authors too. In 2006, the Swedish Academy stated, "In the question for the melancholic soul of his local city, Pamuk has found new images for the conflict and intertwining of cultures", so they granted him the Nobel Prize for literature (Ozgen, 2).

His profound connection to the city is delightfully caught in Istanbul: Memories and the City, a blend of childhood diary and a trip into Istanbul life through his own eyes and those of painters and novelists (consisting of European guests like the German writer, Antoine-Ignace Melling, and the French scholars Gérard de Nerval and Gustave Flaubert), it enlightens the individual and aesthetic impacts on his work (H. E. Almas, 88). Istanbul: 
Memories and the City novel provides an investigation of the mutuality of political change and material culture informing and reshaping social memory (Aljahdali, 117). Conclusion

Orhan Pamuk represents Istanbul as a means to characterize himself, so he proposes in Istanbul: Memories and the City, his personal experiences with sighted and verbal portrayals of himself and the city, so he recognizes himself with the city and shows it as his personal history. In his memoir, Istanbul is more than an existence that the author deals with or sets himself against: it is an unmatched buddy, the main consistent in a changeable world, the focal point to oneself and the human condition. The space that Pamuk's memoir summons is not just geography, however a position of habitation, a locus of both cultural and individual personality. Istanbul presents a sort of changeless destiny. Complicatedly, his destiny and ability to be self-aware are interlaced with the fate of the city. Along these lines, by talking about Istanbul, he discusses himself and the other way around, so the city, for Pamuk, is at the center of his literary work, yet of each text composed in the city. 


\section{Works Cited}

Aljahdali, Samar H. "Architecture and the Insciption of History: Orhan Pamuk's Representation of Istanbul." WIT Press, vol. 177, no. 2, 2018, pp. 117-26, DOI: 10.2495/IHA180091.

Almas, Esra. Capitalizing Istanbul: Reading Orhan Pamuk’s Literary Cityscape. 2018.

Almas, H. E. "Homelessness, Self and the City in Istanbul: Memories and the City." Capitalizing Istanbul: Reading Orhan Pamuk's Literary Cityscape, 2020, pp. 60-83, http://dare.uva.nl.

Anadolu-Okur, Nilgun. Essays Interpreting the Writings of Novelist Orhan Pamuk. 2005.

Brameswari, Catharina. The Irony of Turkish Modern Identity: Oscillation of the East and the West in Pamuk's My Name Is Red and The White Castle. 2015.

Dollar, Cathlene Elizabeth. Identity Formation in the Novel: Orientalism, Modernity, and Orhan Pamuk. 2015.

Manzoor, Saima. "Histories of the Self: A Critical Analysis of Orhan Pamuk's Istanbul: Memories and The City." Paripex-Indian Journal of Research, vol. 5, no. 1, 2016, pp. $226-27$

Martins, Adriana Alves de Paula. "Orhan Pamuk and the Construction of Turkey's National Memory in Istanbul: Memories of a City." Coimbra University Press, 2018, p. 14.

Narayan, Pallavi. "Pamuk's Istanbul: Everday Architecture." Indian Institute of Technology Delhi, no. September, 2016.

Ozgen, Aykun. "Orhan Pamuk in the Context of Istanbul and Authorship: The Black Book, My Name Is Red, Istanbul.” Sabanci University Press, 2013.

Pamuk, Orhan. Istanbul Memories and the City. Trans. Maureen Freely. New

York: Alfred A. Knopf, 2005. Print

Priyadarshini, Suma. "Memoir on Istanbul: A Mirror to Orhan Pamuk's Melacholic Soul." 
IJRAR, vol. 5, no. 4, 2018, pp. 153-54.

Shah, Syed Moniza Nizam. "Orhan Pamuk and the Orient-Occident Dichotomy." International Journal of Advanced Education and Research, vol. 2, no. 4, 2017, pp. $35-38$.

Weder, Nandi. Urban Space in Transformation: Reading Social Change in Vladislavić's Johannesburg, Pamuk's Istanbul, and Dalrymple's Delhi. 2016. 